Portland State University

PDXScholar

\title{
Life styles of methadone treatment patients: agreement of self report and informant report
}

\author{
Richard Cox \\ Portland State University \\ Gary West \\ Portland State University
}

Follow this and additional works at: https://pdxscholar.library.pdx.edu/open_access_etds

Part of the Chemicals and Drugs Commons, Social Control, Law, Crime, and Deviance Commons, and the Social Psychology and Interaction Commons

Let us know how access to this document benefits you.

\section{Recommended Citation}

Cox, Richard and West, Gary, "Life styles of methadone treatment patients: agreement of self report and informant report" (1971). Dissertations and Theses. Paper 1433.

https://doi.org/10.15760/etd.1432

This Thesis is brought to you for free and open access. It has been accepted for inclusion in Dissertations and Theses by an authorized administrator of PDXScholar. Please contact us if we can make this document more accessible: pdxscholar@pdx.edu. 
LIFE STYLES OF METHADONE TREATMENT PATIENTS:

AGREEMENT OF SELF REPORT AND INFORMANT REPORT

By

RICHARD COX AND GARY WEST

A research practicum submitted in partial fulfillment

of the requirements for degree of

MASTER OF SOCIA L WORK

Directed by

VINCENT GLAUDIN, PH. D.

Portland State University

April 15, 1971 
ACKNOWLEDGEMENTS ......................... . . .

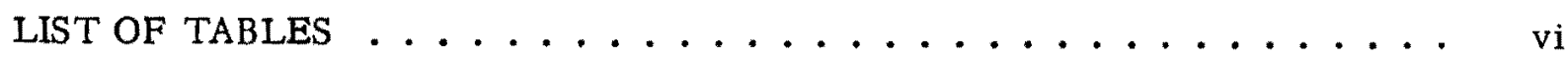

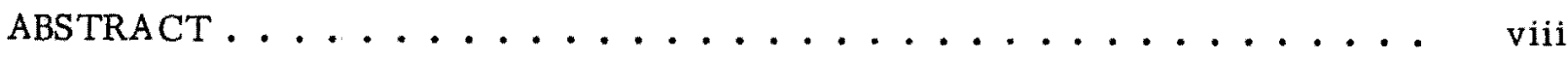

I INTRODUCTION $\ldots \ldots \ldots \ldots \ldots \ldots$

A. Opiate Addiction ......................... 1

B. Addict Life Style.................... 2

C. Methadone Treatment Program ............... 2

D. Oregon Methadone Program ............... 3

E. Statement of Purpose. . . . . . . . . . . . . 4

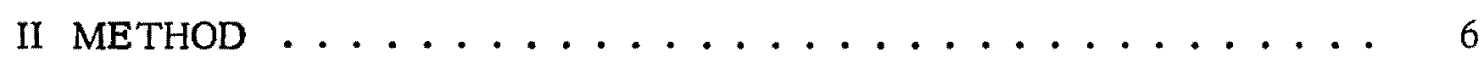

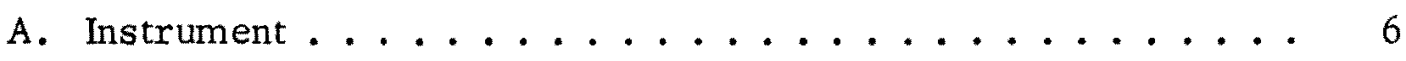

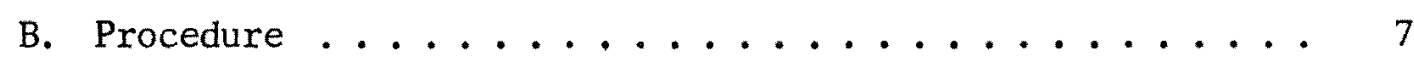

1. Patients ........................... 7

2. Informants ...................... 7

3. Patient Sample: Stratification by Age and Race . . . . . 8

4. Patient Sample Profile ............... 10

5. Patient Sample: Volunteers and "Turndowns" . . . . . 11

6. Informant Sample .................... 11

III $\operatorname{RESULTS} \ldots \ldots \ldots \ldots$

A. Main Results ..................... 13

B. High Agreement Between Patients and Informants . . . . . 13

C. Altered Social Life Pattern ................ 14 
PAGE

1. More Family Life . . . . . . . . . . . . . . 14

2. Friends "Non-Users" ................ 14

3. Little Participation in Organizations ........... 15

D. Responsibility: Living Arrangements and Vocational -

Adjustment ............................. 15

1. Living in a Family Unit . . . . . . . . . . . . 15

2. Alcohol Conflict ................... 16

3. Patterns of Alcohol Consumption and Marijuana Usage . . 16

4. Roommates "Non-Users" . . . . . . . . . . . . . 17

5. Most Employed ................. 17

E. Illegal Activities ................. 18

1. Little Use of Illegal Drugs . . . . . . . . . . 18

2. Arrests and Illegal Income Decrease.......... 21

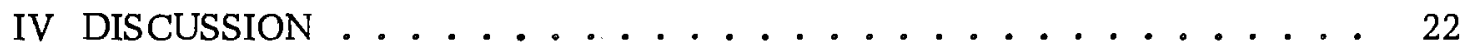

A. General Conclusions ................ 22

B. Modal Patient .................. 22

C. Limitations of the Study ............... 23

D. Negative Features ................. 25

E. Implications for the Methadone Treatment Program . . . . . 26

F. Implications for Research . . . . . . . . . . 27

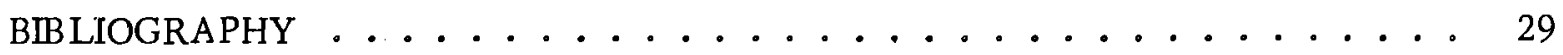

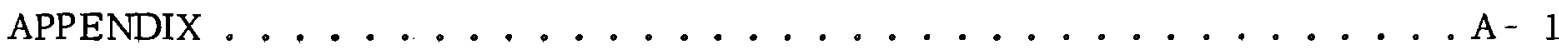

A. Patient Questionnaire and Percentages of Responses ....... A - 1

B. Informant Questionnaire and Percentages of Responses . . . . . A-12 
C. Percentage of Perfect Agreement Between Patient and Informant for Each Question and Product-Moment Correlations for Scalable Items $\ldots \ldots \ldots \ldots \ldots \ldots$. . . . . . . . . . . .

D. Patient Sample Characteristics .............. A 28

E. Informant Sample Characteristics . . . . . . . A - 30 


\section{ACKNOWLEDGEMENTS}

We would like to extend our warmest appreciation to Dr. Paul Blachly, the Director of the Oregon Methadone Treatment Program, and his staff, Dr. Norman David, Mrs. Kathy Rock, and Mrs. Dana Brewster for their invaluable assistance and support in our endeavor. Dr. Blachly's encouragement to utilize informants disuaded us from carrying out a less meaningful study. We also express gratitude to Dr. Gaylord Thorne, Research Coordinator for the Oregon State Board of Mental Health; and to Dr. Arthur Emlen, Profess or of Social Work, Portland State University. These two individuals facilitated the early stages of our research as well as graciously advising us on the format of the questionnaire. 


\section{LIST OF TABLES}

TABLE

PAGE

I AGE DISTRIBUTION OF ALL BLACK AND WHITE MALES PARTI-

CIPA TING IN THE OREGON METHADONE TREATMENT PRO -

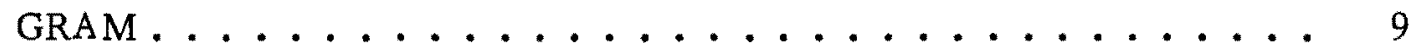

II AGE-RACE STRATIFICATION OF THE PATIENT SAMPLE

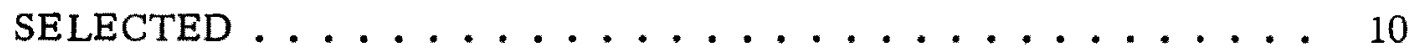

III TIMES PER MONTH INFORMANTS HAD CONTACT WITH THE

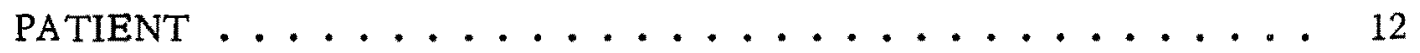

IV SIMILARITY OF AVERAGE RESPONSE CA TEGORY FREQUENCIES

FOR PATIENTS AND INFORMANTS: AN ILLUSTRA TIVE ITEM . . . 14

$\checkmark \quad$ USE OF NARCOTICS BY METHADONE PATIENT'S FRIENDS . . . . 15

VI LEGITIMATELY EARNED INCOME PER WEEK . . . . . . . 18

VII TYPES OF ILLEGAL DRUGS USED BY METHADONE PATIENTS . . . 19

VIII FREQUENCY OF ILLEGA L DRUG USAGE . . . . . . . . . 20

IX ILLEGAL INCOME OF METHADONE PATIENTS . . . . . . . . 21

THE FOLLOWING TABLES ARE IN THE APPENDIX:

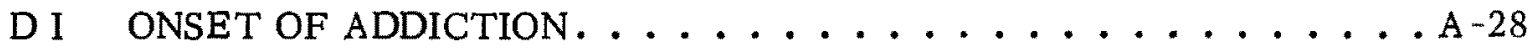

D II NUMBER OF YEARS NARCOTICS USED . . . . . . . A A-28

D III NUMBER OF PRIOR FORMAL TREATMENTS . . . . . . . . A A-28

D IV NUMBER OF MONTHS ON METHADONE . . . . . . . . A -28

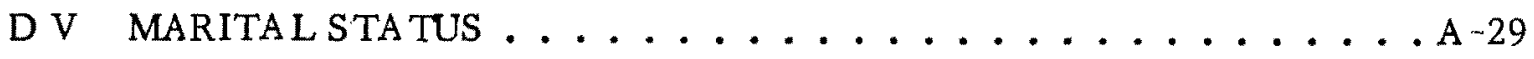

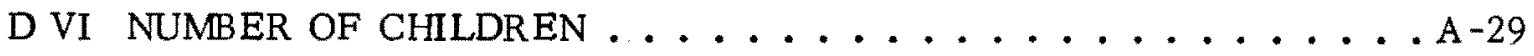

D VII LEVEL OF EDUCATIONAL A CHIEVEMENT . . . . . . . . . A-29 


\section{CONTINUED}

TABLE

PAGE

E I RELATIONSHIP OF THE INFORMANT TO THE PATIENT . . . . A A -30

E II LENGTH OF TIME INFORMANTS HAVE KNOWN THE PATIENT • . A -31

E III TIMES PER MONTH INFORMANTS HAD CONTACT WITH THE

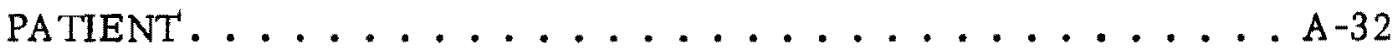


The purpose of this descriptive study was to reveal the typical life style of a representative sample of fifty male opiate addicts participating in the Oregon Methadone Treatment Program. An important goal of the research was to asess the reliability of information gathered from patients compared to data obtained from an equal number of informants. A highly structured questionnaire was designed to elicit specific responses in order to calculate the degree of concordance between patients and informants to identical items. The findings depicted the modal life style of the subjects as more socially conventional, more responsible, and less antisocial. Although only $20 \%$ of the patients occasionally used heroin, it was common for them to rely on alcohol or marijuana. The results showed a pattern of high agreement between patients and informants in the information they provided sug gesting that the data were reliable. It is judged that the self report of methadone patients should be given considerable credence when information is gathered in a context of trust and confidentiality. The investigators conclude that the Oregon Methadone Treatment Program deserves the full support of the community as one with significant dividends to the patients and to the state. 


\section{INTRODUCTION}

\section{A. Opiate Addiction}

The United States in the seventies has been described as a drug-oriented society given to the immediate gratification of the seductive behaviors (Blachly, 1970). While the list of chemical substances commonly abused for altering mental states is long indeed, the drugs fall mainly into three catagories: depressants, stimulants, and hallucinogens. Opiates are classified under the first heading, nervous system depressants. The sought after subjective effect, however, is a release from realistic concerns in a pleasant euphoria. This sense of well-being or "high" can be produced by opium, morphine, heroin, paragoric, and codeine; among others, all of which are classified as opiates. The drive for this altered state of consciousness becomes very intense in some people whose continued use of opiates produces a true addiction.

Addiction to opiates is a psychophysiologic dependency where sudden withdrawal of the drug leads to a distressing abstinence syndrome, marked by chills and nausea, which is called "withdrawal sickness". The opiate addict, therefore, not only seeks a pleasant euphoria but he attempts to avoid the discomfort of withdrawal sickness. While it is popular to picture the individual caught in this trap of opiate addiction as a grossly abnormal deviate, there appears to be increasing evidence that opiate addiction reaches into every group or social class. Based on March, 1971 figures, the National Institute of Mental Health estimated there were as many as 200,000 opiate addicts in the U.S. . In Oregon the total number of opiate addicts is unknown: yet, estimates set the total at 1500 (Progress Report to Oregon Legislature July 1, 1970) . 


\section{B. Addict Life Style}

Opiate addiction is especially significant to society because the addict's life style and its intimate association with crimes touch every citizen, either directly or through the erosion of honest government. Although addiction to opiates is probably not harmful physically, it may cause death indirectly from overdose or hepatitis from contaminated injections. On the other hand, opiate addiction may affect every aspect of life style including strained social relationships, reduced productivity, and increased preoccupation with self, as the addict is driven to satisfy his craving for opiates. The addict:'s entire life style may be oriented around financing his costly habit. Supplying an addiction may range as high as two hundred dollars a day. Confronted by this exhorbitant cost of opiate addiction, many addicts turn to illegal activities to pay for their hunger for drugs. Our society's response has largely been reflexive to the criminal role of the opiate addict; law enforcement and punishment have characterized our approach to addiction without notable success. In fact, there is some evidence that drug abuse has grown in this country, a kind of "cops and robbers game", as punitive legislation has proliforated since the turn of the century (Doerr, 1968).

\section{Methadone Treatment Programs}

An alternative to punitive approaches to addiction, on the one hand, and ineffectual "bleeding heart" concern on the other, has been the development of methadone main. tenance treatment programs. Methadone, a synthetic narcotic, was first synthesized in Germany in 1941. Methadone maintenance consists of substituting methadone for heroin and other opiates. Taken orally once every twenty four hours, methadone eases opiate withdrawal, helps maintain emotional stability, and gradually forms a physical blockade to the euphoric effects of opiates. Since methadone appears to produce no significant debilitating side effects, it offers the opportunity for the patient to return to 
more normal functioning. Moreover, in addition to its effectiveness in blocking the value of opiates to the addict, methadone is inexpensive. It can be dispensed on an outpatient basis by oral dosage averaging about one dollar per day per patient.

The first program to use methadone as a treatment modality was initiated in New York City in 1964 under the direction of Dole and Nyswander. The effectiveness of methadone as a physical blockade to the euphoric and debilitating effects of opiate usage was reported by Dole, Nyswander, and Kreek (1966). Subsequently, this same group claimed that their methadone maintenance treatment program produced a significant reduction of criminal activity and an increase in employment in their patients (Dole, Nyswander, and Warner, 1968). Reduction in both criminal behavior and the use of heroin was further demonstrated by Dole, Robinson, Orraca, Towns, Searcy, and Caine (1969) ; however, little attention has been given to describing the life styles of methadone maintenance patients. For instance, the literature seems to be devoid of descriptions of the patient's social readjustment or degree of integration into the "straight life".

In the brief period since the first program was started, approximately sixty programs have been noted nationally and the best present estimate is probably 260 methadone treatment programs in operation in this country (Blachly, 1971). In assessing the effectiveness of methadone treatment, it is important to keep in mind that these programs vary greatly in the way they function and integrate adjunctive services (Ramer, 1971).

\section{Oregon Methadone Program}

In 1969 the Oregon Legislature passed HB 1691 which permitted the establishment of a methadone maintenance treatment program in this state. On April 2nd of that year, the Oregon program began with the treatment of two patients under the care of Dr. Paul Blachly, Director. This local program under Blachly's direction 
was established in the Oregon Alcohol and Drug Section, Mental Health Division. By January 1971 , this Portland based clinic was maintaining 328 patients on the methadone blockade program.

The Oregon Methadone Treatment Program is unique in that it has been described as the "simplest" (Blachly, 1970). This local program is supported primarily by the patients themselves in conjunction with community resources, illus trating a relatively low cost operation. Patients pay one dollar for the daily methadone dose which is administered orally in one of three carefully selected drug stores. Their drug usage is monitored by laboratory tests and brief contacts at the Alcohol and Drug Section Clinic in Portland. No elaborate psychotherapeutic or special rehabilitation effort was mounted. Obviously some rehabilitation services were offered through normal channels by agencies available in the community. Moreover, a few methadone patients found their way into therapy groups in the Alcohol and Drug Clinic.

This modest program appeared to bear fruit in decreased heroin usage, increased employment, and improved social adjustment. Perhaps the most significant finding presented in the "Progress Report of Synthetic Narcotic Blockade Treatment Program 1970" (Oregon Advisory Committee Relating to Drug Dependency) was the apparent decline in illegal activities engaged in by methadone maintenance patients. The Oregon program is believed to be producing sharp increases in employment among methadone patients, continuous decrease in heroin usage, and indications of gradual increases in more acceptable social behavior.

\section{E. Statement of Purpose}

The present study is concerned with the adjustment of patients participating in the Oregon Methadone Treatment Program. This concern is broad rather than being limited to possible decrease in antisocial behavior. Further, this investigation is 
directed as one form of objective evaluation of the effectiveness of a program which has been under polemic attack (Erickson, 1970). Hopefully, careful description of the adjustment of methadone patients might lead to recommendations for bolstering the program. This is especially possible because the Oregon Methadone Treatment Program is intentionally relatively narrow. Should the program be elaborated by other treatment modalities? Are there any clues to points of vulnerability of an otherwise successful patient?

The broad purpose of this descriptive research has come to focus on two main questions:

(1) What is the typical life style of methadone maintenance patients as they describe it?

(2) How reliable are reports gathered from methadone maintenance patients when compared to data provided by informants? 


\section{METHOD}

\section{A. Instrument}

A highly-structured questionnaire (Appendix A and B) was designed to gather specific data and to provide an opportunity for careful comparison of patients' and informants' responses to identical items. The questionnaire was constructed under three main headings:

(1) Social Activities - Nine items were selected to describe the patients range and frequency of social behavior; number and types of friends; and family relationships.

- (2) Responsibility - Ten items were intended to describe the patient's acceptance of responsibility in employment, care for dependents, steps toward self im provement, and coping with alcohol as a legally available substitute.

(3) Illegal Activities - Eleven items which tried to expose and calibrate the patient's status with the law, illegal sources of income, and use of illegal drugs.

Most of the questions which composed the questionnaire were drawn from established sources so that considerable pre-testing of items had been carried out. These items held the further advantage in that some degree of reliability had been established for other populations so that some comparison might be possible, e.g. rate of employment compared between methadone patients and post-hospital mental patients. The main sources for items were as follows: a) Personality Attitude and Rating Scale (Ellsworth, 1968); b) Problems of Drug Dependency (Report to Committee on Problems of Drug Dependency 1970), c) Weekly Activity Summary, which patients fill out each time they come to the Oregon Methadone Treatment Program Clinic. A few additional questions were developed by the investigators to fill gaps to give a more comprehensive 
view of the patient's personal-social functioning. Nevertheless, the research team limited the questionnaire to thirty items in order to promote cooperation and high quality data.

\section{B. Procedure}

1. Patients:

Since both research interviewers spent over three months attending the Oregon Methadone Treatment Program group clinic with patients and familiarizing themselves with the setting, the transition to introducing the questionnaire was relatively easy. At this point the interviewers were identified by the patients as a peripheral part of the treatment program. Moreover, the data were collected with the full support and assistance of the methadone clinic staff which greatly facilitated the process of administering the questionnaire.

The questionnaire was handed to the patients individually in the clinic by a research team member and it was completed in his presence. Although the approach to the patient blended in with the clinic operation as "just routine", it was made clear to the patient that he was being asked to volunteer information which might be useful in improving program services. The instructions stressed the confidentiality of the volunteered information and the fact that questionnaire responses would in no way hinder or alter the individual's present treatment.

\section{Informants:}

On the last page of the patient's questionnaire, the name of an informant was obtained. The patient authorized the research team to contact the informant and he gave written permission for the informant to complete the questionnaire. It was stressed that the informant to be named be a person who knew the patient well, not only at the present time, but also before the patient began methadone treatment. The final 
criterion was that the informant be available in the Portland metropolitan area.

Usually within a week after the patient gave his responses to the questionnaire, the informant was contacted by phone for an appointment. It was clearly stated to the informant that the patient had given permission for the contact but that the informant's assistance was strictly voluntary. To reduce interviewer bias, the research team member who had contact with a given patient did not contact that particular patient's informant. In this way, two interviewers systematically reversed patient and informant contact for each case. Interviewers handed the questionnaire to the informants individually and remained present during the time it was being completed. As with the patients, the informants who responded to the questions did so with the understanding that the study was designed to see how the treatment program was meeting the patient's needs and how it might be improved. Thus, the method of administration of the questionnaire was held constant with the exception that informants were interviewed in their homes rather than at the clinic.

3. Patient Sample: Stratification by Age and Race:

As of the first part of January, 1971, the Oregon Methadone Treatment Program had a total patient load of 328 . Of this population, 216 patients were white or black males (the rest of the population consisted of 99 females, and 11 males from Chinese, Indian, and other minorities). It was decided to limit the sampling for the study to the main segment of the treatment population, the $66 \%$ who were white or black males. This decision was made to reduce some of the sources of variance in results so that trends or typical patterns might be more likely to emerge. The characteristics of this patient population which was subsequently sampled are shown in Table I. 
TABLE I

\section{AGE DISTRIBUTION OF A LL BLACK AND WHITE \\ MALES PAR TICIPA TING IN THE \\ OREGON METHADONE TREATMENT PROGRAM \\ JANUARY, 1971}

$$
N=216
$$

Age

White

Black

21 and under

$$
21=10 \%
$$$$
3=1 \%
$$

$22-30$

$77=36 \%$

$26=12 \%$

$31-40$

$32=15 \%$

$26=12 \%$

41 and over

$\underline{17=8 \%}$

$\underline{14=6 \%}$

Total

$147=69 \%$

$69=31 \%$

A stratified sample of 50 male subjects was selected randomly by race and age in an effort to replicate the characteristics of the total 216 black or white males in the treatment program. This task was accomplished by selecting patients in the order they came to the clinic but excluding a potential subject once the quota for a given stratum had been filled, e.g. a patient might not be accepted because the quota of white males over 40 had been reached. The only other criterion for selection in the study's sample was participation in the treatment program for at least three months. This requirement was meant to allow time for adjustment of methadone dosage and some change in life style (Blachly, 1969). Following this sampling procedure, the 50 patients who participated in the study had age-race characteristics as shown in Table II, an almost perfect duplication of Table I. 
TABLE II

AGE-RACE STRATIFICATION OF THE PATIENT SAMPLE SELECTED

$$
N=50
$$

Age

White

Black

21 and under

$$
5=10 \%
$$

$1=2 \%$

$22-30$

$18=36 \%$

$6=12 \%$

$31-40$

$8=16 \%$

$6=12 \%$

41 and over

$3=6 \%$

$3=6 \%$

Total

$34=68 \%$

$16=32 \%$

\section{Patient Sample Profile:}

Roughly half of the sample of male patients were between 22 and 30 years of age. Every third patient was black. Over two-thirds of these men had become addicted to opiates when they were between 13 and 20 years old. As a group they averaged six years of opiate usage with approximately half of the patients giving the his tory of at least one previous treatment failure. Although the minimum participation of the sample in the Methadone Treatment Program was three months, three-quarters of the patients had been taking methadone for over six months.

Half of the men in the patient sample were married at the time the data were collected for this study, A little more than half reported they had one or two children. The modal patient was a high school graduate or drop-out who had subsequently earned a GED status. (See Appendix D for the tables detailing the patient characteristics dis cussed in this section). 
5. Patient Sample: Volunteers and "Turndowns":

There were six patients who refused to cooperate with the study. They gave a variety of reasons for rejecting the research but one theme was the concern for contacts with informants. One patient said, "I simply don't want to be bothered". Another asserted, "There's no such thing as confidentiality". A third claimed, "You already have that information". The three patients who would not cooperate because of informants included one who said he was new to the area and could not provide a person meeting our ctrteria. The remaining two were keeping their participation in the treatment a secret so they were defensive about any threat to anonymity: "I don't want anyone from this program talking to my people!" Obviously the rights of these patients to remain outside the study were respected. The 50 patients who did participate represented, therefore, an $88 \%$ volunteer rate which is generally accepted to be extremely high for any type of research.

6. Informant Sample:

All the informants named by patients were approached and $100 \%$ of these voluntarily coopera ted with the research project. Almost half of the informant sample were spouses. A few of these wives were on the methadone program while still others were actually common-law partners. Another large category of informants, comprising about one-third of the sample, were parents of the patients. Only about one-quarter of the informants were friends or miscellaneous contacts. These informants, by the very nature of their relationship, were well acquainted with the patient for many years. $90 \%$ of the informants had known the patient for at least one year while three-quarters of the informants knew the patient for a minimum of two years. Not only had the informants' relationship. with the patients been long established, but three quarters of them had contact with the patient at least 21 times during the month about which they were 
querried. $90 \%$ of the informants had at least 11 contacts with the patient during the month described by the data. (See Table III. Refer to Appendix E for the complete breakdown of results concerning informants).

Table III

TIMES PER MONTH INFORMANTS HAD CONTACT WITH THE PATIENT

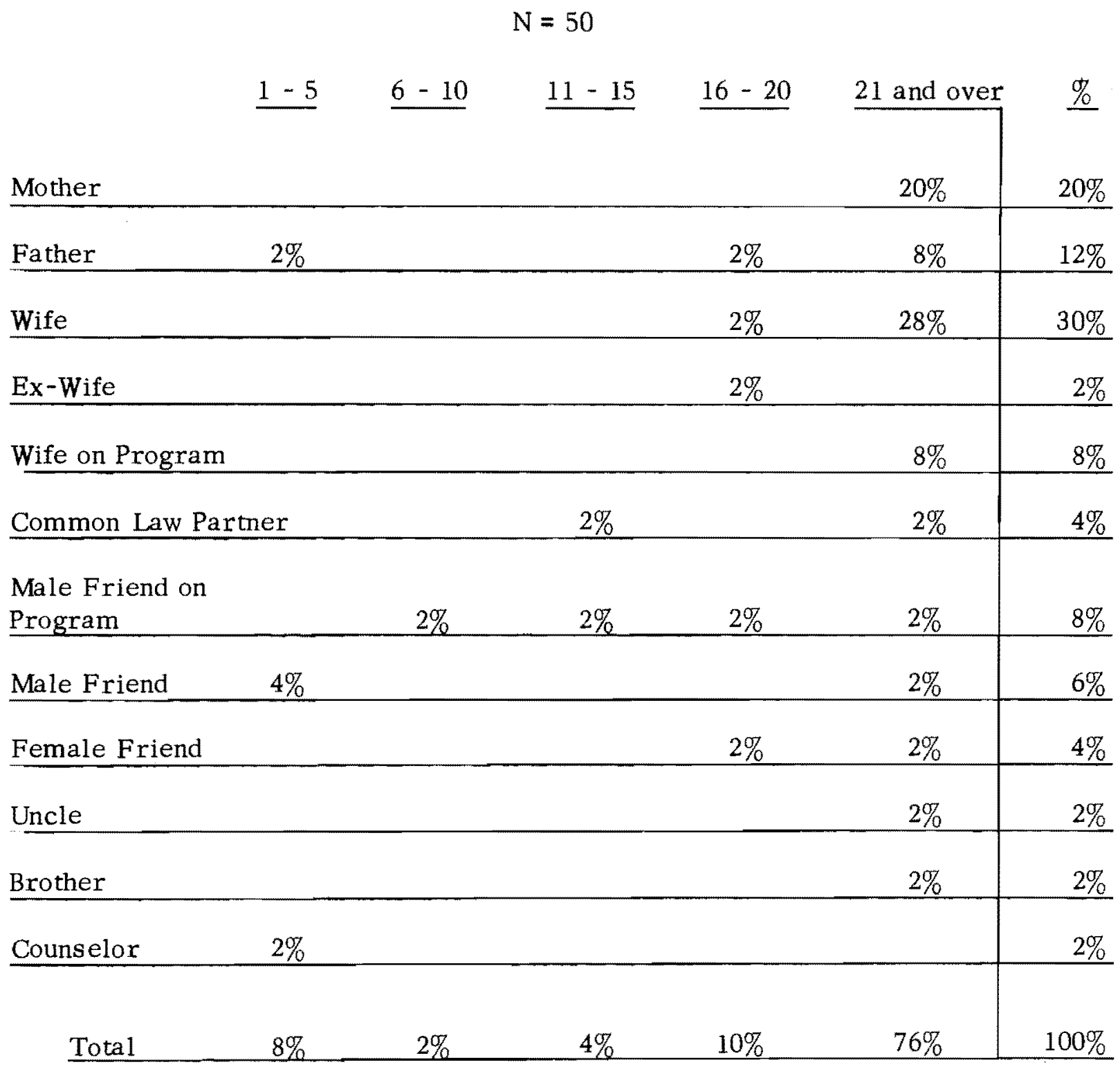




\section{RESULTS}

A. Main Results

The data suggest that the two main questions of the study were answered affirmatively. First of all, the findings describe the life style of the patient-subjects as more socially conventional, more responsible and less antisocial. Secondly, the results show a pattern of high agreement between patients and informants in their responses to questions. Generally the data are reported in terms of the percentage of subjects selecting a given response and the percentage of agreement between patient and informant in selecting a response category. Percentage of "perfect agreement" means indentical category selection by patient and informant. Where the items permit the assumption of an ordinal scale, Pearson product-moment correlations are reported as well. Detailed description of the results may be found in Appendix A, B, and C.

\section{B. High Agreement Between Patients and Informants}

Identical responses were given to questions by patients and informants on approximately $\% 0 \%$ of the 1 tems, where chance agreement ranged from about $10 \%$ to $50 \%$ depending on the number of categories. Percentage of perfect agreement in describing "social life" was 51\%; "responsibility", 76\%; and "illegal activities", 80\%. Ranges of the percentage of perfect agreement for these three divisions of the questionnaire were $33 \%-74 \%, 61 \%-95 \%$, and $62 \%-100 \%$ respectively. The average r's for the few scalable items in each section were $.32, .65$, and .39 in that order. Not only was there this form of evidence that agreement exceeded chance, but the pattern of the percentages of response to the various categories tended to be similar. This is illustrated by the example item show in Table IV. When there were differences 
between patients and informants, the direction of the difference was usually random although in some instances the patient admitted to more antisocial behavior than the informant reported about him.

Table IV

\section{SIMILARITY OF AVERAGE RESPONSE CATEGORY FREQUENCIES FOR PATIENTS AND INFORMANTS:}

\section{AN ILLUSTRA TIVE ITEM}

During the last month have you looked for work or obtained employment?

$$
\text { Patients Informants }
$$

unemployed, didn't want to look for work

unemployed, wanted to work but didn't seek it

occasionally went out and looked for work

frequently went out and looked for work

was employed

$$
2 \%
$$

$6 \%$

$13 \%$

$14 \%$

$65 \%$

$6 \%$

$6 \%$

$12 \%$

$15 \%$

$61 \%$

C. Altered Social Life Pattern

1. More Family Life:

The data indicated that some types of social activity increased while others decreased for patients participating in methadone treatment. Overall findings suggest a more conventional social life but a relatively restricted one. A central trend was improved family relationships in about one-third of the cases and increased family contact in about half the cases. A modal patient in the treatment sample was a married man with few friends and little participation in organizations or recreation.

\section{Friends "Non-Users":}

Over half the patients and informants disclosed that the methadone patient had 
one to three friends. At the extremes, about one in six patients had no friends at all and one in six had many friends, i. e. at least seven. Patients and informants agreed that there were more cases of decreased "going out with friends" than increased friend contact. $72 \%$ of informants reported a decline in this kind of patient social activity. In the same vein the type of friendships maintained may have changed in that few friends were drug users, according to the results displayed in Table V.

\section{Table V}

\section{USE OF NARCOTICS BY METHADONE PATIENT'S FRIENDS}

Patient report

Non-users
Ex-addicts
Addicts
No Friends
$58 \%$

$20 \%$

$8 \%$

$14 \%$
Informant report

$53 \%$

$22 \%$

$11 \%$

$14 \%$

\section{Little Participation in Organizations:}

There was only moderate agreement that methadone patients participated minimally in organizations or social clubs. Patients and informants alike reported that over three out of four patients did not attend any activities of this type during the reporting period. One in four patients and one in five informants mentioned that the patient was involved with a social organization during the previous month. If recreational activities and outside interests are combined, the average participation by methadone patients fell in an estimated range of two or three times per month.

D. Responsibility; Living Arrangements and Vocational Adjus tment

1. Living in a Family Unit:

Three out of five patients in the sample were living with their parents or with their 
wife and children. The family unit usually resided in a one-family house or apartment. This finding was reported with $88 \%$ perfect agreement by patients and informants Patients also lived with relatives or common-law wives so that only about $20 \%$ were living alone at the time the reports were made,

\section{Alcohol Conflict:}

Although the majority of methadone patients reported no excessive drinking during the previous month, the remainder described moderate to heavy excessive drinking. About $40 \%$ of the patients admitted to an amount of alcohol dependence to be considered habitual excessive drinkers (Diagnostic and Statistical Manual of Mental Disorders, 1968). The rate of perfect agreement on the amount of drinking was $62 \%$ with a highly significant $r .60$. There was even higher agreement (95\%) that drinking was significant enough to upset the patient's relationship with his family. Onethird of the patients admitted this while one-half of the informants reported the abuse of alcohol as a problem.

The percentage of patients who reported excessive drinking were very similar in number to those using marijuana. The question arises, do these two groupings overlap?

3. Patterns of Alcohol Consumption and Marijuana Usage:

In comparing those patients who reported some usage of marijuana and alcohol comsumption reaching the point of excess some significant data were revealed:

(1) $42 \%$ of the male patients reported that they never drank to excess, nor smoked marijuana during the month under evaluation.

(2) $24 \%$ of the sample disclosed that they drank to excess. This group reported no use of marijuana.

(3) $18 \%$ of the patients acknowledged that they used some marijuana, No excessive alcoholic consumption was reported in this group.

(4) Only $16 \%$ of the sample reported that they used both alcohol to excess and 
marijuana. The breakdown in this category was as follows:

(a) $6 \%$ consumed alcohol in excess 1-3 times/month and used marijuana 1-5 times/month

(b) $2 \%$ consumed alcohol in excess 3-5 times/month and used marijuana 6-10 times/month

(c) $2 \%$ consumed alcohol in excess 6-12 times/month and used marijuana 11-20 times/month

(d) $2 \%$ consumed alcohol in excess 6-12 times/month and used marijuana 21-30 times/month

(e) $4 \%$ consumed alcohol in excess 6-12 times/month and used marijuana over 30 times /month

Somewhat less than half of the sample indicated that they did not abuse alcohol by excessive drinking or use marijuana. However, $42 \%$ of the patients reported that they utilized only one of these depressants, while $16 \%$ used both alcohol in excessive amounts, and marijuana to varying degrees. (See Appendix A and B for a complete breakdown of excessive alcohol consumption and usage of marijuana)

\section{Roommates "Non-Users":}

Two-thirds of the roommates of methadone patients in the sample have never used illegal drugs according to the data. In $18 \%$ of the cases, those with whom the methadone patient was rooming were ex-addicts; some were also methadone treatment patients. About one in six or seven of the roommates were described as "heavy" users of alcohol. Percentage of perfect agreement in depicting the drug status of room mates was a very high $91 \%$.

\section{Most Employed:}

Almost two-thirds of the patients in the sample were employed during the report period and about $20 \%$ were involved in either vocational training or formal education. Perfect agreement peraentage was $70 \%-72 \%$ in reporting employment and training or education. The remaining number of patients for the most part stated that they oc- 
casionally looked for work or they expressed a desire to receive training. The patients who were employed $(61 \%$ to $65 \%)$ considered their jobs to be stable ones in three cases out of four. Although the percentage of perfect agreement was $76 \%$, this was one of the few points in the study where the patient may have tended to up-grade himself com pared to the informant's judgment about the job situation. Certainly the vocational status of the patient sample, as measured by earned income, was modest. The mean earned income as reported by patients was $\$ 65.00$ per week and $\$ 55$ per week according to informants. A highly significant $r$ of .65 was established between patients and informants in rating of legitimately earned income. They also agreed that this source of income was adequate enough to support only the patient himself. The range and pattern af income earned by patients is presented in Table Vl.

\section{Table VI}

LEGITIMATELY EARNED INCOME PER WEEK

$\begin{array}{lcc} & \begin{array}{c}\text { Patient Report } \\ \mathrm{N}=50\end{array} & \begin{array}{c}\text { Informant Report } \\ \mathrm{N}=49\end{array} \\ \text { Earned no money } & 20 \% & 29 \% \\ \text { Earned less than } \$ 25 & 8 \% & 11 \% \\ \text { Between } \$ 25 \text { and } \$ 50 & 14 \% & 2 \% \\ \text { Between } \$ 50 \text { and } \$ 100 & 32 \% & 33 \% \\ \text { More than } \$ 100 & 26 \% & 25 \%\end{array}$

E. Illegal Activities

1. Little Use of Illegal Drugs:

A minority of patients used illegal drugs during the month under examination according to the consensus of patient and informant reports, Only $20 \%$ of the methadone 
patients used any heroin at all as judged by these data. Usage ranged from $0 \%$ for psychedelics to $34 \%$ for marijuana. It should also be recalled (page 16) that alcohol was used excessively by about this same percentage of patients turning to marijuana. As Table VII details, there was surprisingly high agreement between patients and informants concerning the usage of specific illegal drugs. The table also reveals that the patients consistently admitted to more illegal drug usage than informants described.

Table VII

TYPES OF ILLEGA L DRUGS USED BY METHADONE PATIENTS

$\begin{array}{lccc}\text { Drug } & \begin{array}{c}\text { Patient Report } \\ \mathrm{N}=50\end{array} & \begin{array}{c}\text { Informant Report } \\ \mathrm{N}=40^{*}\end{array} & \% \text { Agreement } \\ \text { Heroin } & 20 \% & 2 \% & 81 \% \\ \text { Other Opiates } & 8 \% & 2 \% & 89 \% \\ \text { Drug Store Medicine*** } & 8 \% & 8 \% & 84 \% \\ \text { Cocaine } & 4 \% & 2 \% & 93 \% \\ \text { Barbiturates } & 6 \% & 2 \% & 91 \% \\ \text { Amphetamines } & 16 \% & 4 \% & 80 \% \\ \text { Psychedelics } & 0 \% & 0 \% & 100 \% \\ \text { Marijuana } & 34 \% & 12 \% & 62 \% \\ \text { Other Narcotics } & 4 \% & 4 \% & 94 \%\end{array}$

"Informant N 40 because $10 \%$ of this sample reported "don't know"

**"Drug store medicines" were not technically illegal but contained narcotics.

Not only was there good agreement that only a minority of methadone patients used illegal drugs during the report period, but there was agreement that those patients who were users did not take these drugs on a daily basis. For example, the ten patients who used heroin did so 6-10 times per month, according to their own report, and 1-5 times per month as noted by informants. Marijuana, the illegal drug that one-third 
of the patients admitted using, was also the drug used most frequently: 11 to 20

times per month according to both patients and informants. Table VIII gives the complete breakdown of the frequency of illegal drug usage by a minority of methadone patients.

Table VIII

\section{FREQUENCY OF ILLEGAL DRUG USAGE}

\begin{tabular}{|c|c|c|c|c|}
\hline \multirow[t]{2}{*}{ Drug } & \multicolumn{2}{|r|}{ Patient Report } & \multicolumn{2}{|c|}{ Informant Report } \\
\hline & $\mathrm{N}$ & $\begin{array}{l}\text { Times Per Month } \\
\text { (Average) }\end{array}$ & $\mathrm{N}$ & $\begin{array}{l}\text { Times Per Month } \\
\text { (Average) }\end{array}$ \\
\hline Heroin & 10 & $6-10$ & 1 & $1-5$ \\
\hline Other & 4 & $1-5$ & 1 & $1-5$ \\
\hline Drug Store Medicines & 4 & $8-12$ & 4 & $11-20$ \\
\hline Cocaine & 2 & $1-5$ & 1 & $1-5$ \\
\hline Barbiturates & 3 & $1-5$ & 1 & $1-5$ \\
\hline Amphetamines & 8 & $8-12$ & 2 & $1-5$ \\
\hline Psychedelics & 0 & 0 & 0 & 0 \\
\hline Marijuana & 17 & $11-20$ & 6 & $11-20$ \\
\hline Other Narcotics & 2 & $8-12$ & 2 & $8-12$ \\
\hline
\end{tabular}

The picture of low to moderate usage of illegal drugs by the sample of methadone patients is supported further by an examination of expenditures for these drugs. $64 \%$ of the patients and $75 \%$ of the informants reported no money spent on illegal drugs during the previous month. However, about one-third of the patients admitted spending $\$ 1-\$ 50$ per week in this way. Of the entire 50 patients in the sample, there was one man who was spending large amounts of money illicitly ( $\$ 300$ to $\$ 500$ per week). 
2. Arrests and Illegal Income Decrease:

About one quarter of the methadone patients sampled were under legal pressure to continue in the treatment program. This same percentage were on probation during the first month of the program, but the number rose to $38 \%-42 \%$ on probation during sometime on the program. One patient in ten was picked up by the police during the one month report period in terms of the data provided by both patients and informants (85\% agreement, $r .45)$. One year prior to methadone treatment over half the patients sampled were reported as never being arrested while the remainder were arrested 1-4 times (65\% agreement, $r .35)$. Since starting on the program the patients and informants indicated approximately $70 \%$ of the patients were not arres ted with the other patients sampled being arrested 1-4 times (89\% agreement, $r$.75). Perhaps an even clearer index of low rate of criminal activity in the patient sample is that $80 \%$ of the patients and $85 \%$ of the informants denied all such violation and similar percentages were obtained in respect to illegal income, as presented in Table IX.

Table IX

\section{ILLEGAL INCOME OF METHADONE PATIENTS}

$\begin{array}{lcc}\$ \text { Per Month } & \begin{array}{c}\text { Patient Report } \\ \mathrm{N}=49\end{array} & \begin{array}{c}\text { Informant Report } \\ \mathrm{N}=45\end{array} \\ \$ 0 & 85 \% & 83 \% \\ \$ 1-\$ 50 & 13 \% & 11 \% \\ \$ 51-\$ 100 & & 2 \% \\ \$ 101-\$ 200 & & 2 \% \\ \$ 201-\$ 300 & & 2 \% \\ \$ 301-\$ 500 & 2 \% & \\ \$ 501-\text { or more } & & \end{array}$




\section{DISCUSSION}

\section{A. General Conclusions}

The data suggest that it was possible to obtain the cooperation of a representative sample of male methadone treatment patients as well as a group of informants who were well acquainted with these patients. Over all, information provided by these two sources showed a high degree of agreement as an index of reliability. It is judged that the self report of methadone treatment patients should be givenconsiderable credence when information is gathered in a context of trust and confidentiality. Moreover, the findings strongly support the reports in the literature (Dole and Nyswander, 1966; Ramer, 1971) which claim that methadone blockade is an effective treatment modality for heroin addiction. The results of the present research show that continued use of heroin is largely limited to approximately the $20 \%$ of patients who continue to test the reality of methadone blockade (Blachly, 1970). Other findings indicate that the average methadone treatment patient has engaged in no illegal activity or acknowledged illegal income during the month under study. This is in keeping with the report by Dole et. al. , (1968) that crimes by treated heroin addicts dropped $90 \%$ over a four year period in New York. Life styles of the sample of methadone patients examined here proved to be much less deviate than the antisocial heroin addict al*though there was evidence of marked adjustment stresses in a substantial minority of the men.

\section{B. Modal Patient}

A modal methadone patient in Oregon is a white male in his $20^{\circ} \mathrm{s}$ who has a six year history of heroin addiction and a previous failure in a formal treatment program. This man is participating in treatment voluntarily although it would not be unusual for 
him to be on probation. He is typically living with his wife or parents. Although he is probably employed, he earns only enough money to support himself. He probably spends a little more time with his family while going out less with his old friends. He is not a joiner nor likely to be engaged in active recreational pursuits. This average patient probably does not engage in crime, obtain illegal income or use narcotics. Neither his family or friends tend to be users. Although it is not typical, it would not be uncommon to find a methadone patient depending on alcohol and marijuana. Despite the fact that Oregon's modal methadone patient does indeed appear to be a therapeutic success, some are rather lonely, is olated individuals.

\section{Limitations of the Study}

Generalizations from the data should be limited to males, white or black, who were being treated by methadone blockade in Oregon in 1970-71. It is judged that the sample which was selected is extremely representative of that group and that informants were well qualified to provide corroborating data. However, there are several points which must be raised about the sample. First of all, there were a few patients who refused to cooperate. Were they defensive because their life styles were the most deviate? Even so, an $88 \%$ volunteer rate is conceded to preclude a major exror in generalizing about a population.

This descriptive research should be delimited further by noting that only those patients who had adjusted to the program (a minimum of three months) were in cluded. This criterion allowed time to adjust methadone dosage and provide at least some opportunity for change in life style. It must be kept in mind, however, that the $16 \%$ (Blachly, 1970) of heroin addicts who reject the program in the first three months are excluded from various percentages of success failures. Not only were these very early-phase cases excluded, but there were no long-term 
cases because the Oregon program is a new one. The majority of patients in the sample had been treated for six months at the time of data collection. What happens to patients after six years? The longer period might provide time for some to make great strides in coping with a new way of life while others may well regress to sociopathic patterns just as alcoholics "fall off the wagon".

A central issue in considering the limitations of the study is the method itself: agreement between self report and informant report. Certainly the patients and informants both might share a common bias of presenting a more socially desirable picture of the patient than other facts might warrant. Agreement between patient and informant provides one index of reliability of report without necessarily establishing the validity of the data. A "success" bias on the part of patient and informant could contribute to an unrealistically rosy picture of the methadone treatment program because, of spontaneously shared enthusiasm or because of actual collusion. If this type of bias were significant, it was not apparent to the research interviewers. Both patients and informants appeared candid with the reassurance of confidentiality. Informants were seen promptly, usually within a week, and were eager to talk to someone informed about the program. They were mainly wives and parents who saw the patient regularly. Informants' biggest handicap seemed to be a lack of information in a few areas rather than an unwillingness to share. For example, 20\% could not provide information about the patient's use of illegal drugs, or were they unwilling to risk getting the patient into trouble? The "don't know" category might be a form of benign bias but the more likely interpretation is that the patient had more information about him self and so was able to admit to more antisocial behavior. The authors are inclined to support Ellsworth's report that informants are able to provide significant data: 
"..... the reliability and validity of relatives': ratings appearing equal to those of the staff...... with congruence of adjustment ratings by staff and retatives across different settings" (Ellsworth, 1968, page 1).

\section{Negative Features}

Despite the judgment that the Oregon Methadone Treatment Program is basically successful in achieving its goals, some emphas is should be given to negative data or aspects of failure in given cases. For instance, a number of patients are unemployed and/or have minimum incomes. Some of these men report they have looked for work or are interested in training. In these cases, relying on community resources without special liaison may be insufficient. The danger exists that these men will be an economic burden to their families or to the community - not through crime - but through "welfarism". An unproductive, dependent, bored man is probably a vulnerable man. At least $10 \%$ do engage in petty crime to supplement their modest income although it is on a small scale apparently and does not have the desperation associated with heroin addiction. Moreover, the one case in fifty who continues to use significant amounts of heroin, as well as having a high illegal income, should not be ignored.

Since one-half of the informants report that the ex-heroin addicts abuse alcohol enough to cause family problems, this negative result must be considered further. One-third of the patients admit that this is a valid observation. The amount of alcohol consumption is difficult to judge; however, about $40 \%$ of the patients would probably be diagnosed as chronic alcohol abusers according to psychiatric classification (American Psychiatric Association, 1968). This heavy drinking is shared by at least $20 \%$ of the roommates with whom the patient lives, often a wife or commonlaw partner. It appears that family conflict about drinking is most likely to arise with an older patient who has a wife and children, i. e. where the situation most nearly 
approximates conventional standards. The specter of alcoholism as a "side affect" to methadone treatment has been reported previously (Pearson, 1970). To the extent that this is true, the methadone patient may place a new burden on the public in addition to using a drug which is physically much more destructive to him than heroin. It is generally accepted that physical damage related to heroin is indirect, largely a matter of overdose and infection; however, alcohol is consistantly destructive physically since it is known to cause brain damage, peripheral neuropathies, liver disease, gastritis, esophageal hemorrhage, etc.

\section{E. Implications for the Methadone Treatment Program}

The results of this study are interpreted to mean that the Oregon Methadone Treatment Program deserves the full support of the community. It is a simple program where the patients contribute to its modest budget. Data, judged to be reliable, point to significant dividends to the patients and to the state, However, this purposely uncomplicated program probably needs to be expanded in the scope of its approach. It may well be that the elaboration of the program could be carried out on a research basis to determine whether the additional rehabilitation effort actually has significant cost-benefit value. Systematic introduction of a single new modality might be preferable to a complex package of innovations. Moreover, base rates of problem behaviors, such as drinking, should be established prior to addition of specialized services to a portion of the patients.

There are many points where the methadone program might be bolstered. The data suggest that vocational-educational services, treatment for alcoholism, and expanded social-recreational activities are promising points of intervention. For example, patients may need training on recreational alternatives to the drug culture. 
There will always be a need for outreach in the sense of communication with the legalpenal system to get patients involved in treatment; and, on the other hand, facilitating entry into the "square world" so that rebuffs to the highly motivated patient are reduced. Crisis centered psychotherapy for the individual or his family should be considered; however, orthodox psychotherapy is probably not appropriate. Since almost all of these resources are available in the community, perhaps what is needed is an ombuds man to review cases, motivate patients, and smooth liaison with specialized treatment to make sure they are fully utilized.

A surprising number of patients have someone close to them who cares about their progress. This is probably associated. with the relative youth of most methadone patients. Wives and parents especially appeared very responsive to the interest shown by their research interviewers. In all likelihood these family members are an important resource in the rehabilitation of the methadone patient and yet many may be reinforcing deviant behaviors, e.g. "alcohol game" (Berne, 1964). Moreover, half of these family members believe there is a significant alcohol problem. All of these factors point to family therapy (Satir, 1964; Haley, 1963; Framo, 1965; etc.) for selected cases as a new treatment modality which should be entertained seriously.

\section{F. Implications for Resebrch}

Although some of the implications for research are apparent in section $\mathrm{E}$. above, there are some which grow directly out of this study and its method which should be mentioned. One implication is the need to follow up the patients who provided the data for this study as a longitudinal investigation. A description of stages of adjusting to the methadone treatment program would be useful and might provide data on periods of vulnerability to various forms of disturbed functioning. This in turn would provide more intelligent guesses in pinpointing additional services. A new sample of patients 
might also be followed from the earliest point of participation or from the three-month point. In any event, we need to understand the adjustment of the patient through time and the adjustment of the patient who has been on the program several years.

Another study, essentially using the present method, would be a matter of obtaining information about patients who were deliberately excluded from the present des criptive research. Foremost would be the need to describe the fairly large number of women who are being treated for heroin addiction. At the time this study began, there were 99 such cases in Oregon so that this sample is a significant one in several ways. As in most formal research, emphasis has been on studying men, neglecting our: knowledge of deviant behavior in women.

From a methodoligical standpoint, in addition to the immediate practical value, it would be important to determine to what extent a given degree of agreement between a patient and informant does indeed correlate with some independent validity criterion. One might, of course, consider the informant's report to be a kind of validity criterion but the authors prefer to use this as reliability measure. Does a given level of reliability predict an independent validity criterion such as the police record of arrest? When patient and informant reach $85 \%$ agreement, is that agreement closely associated with an employer's records? These are all challenging questions with implications beyond the treatment of heroin addicts per se. 


\section{BIBLIOGRAPHY}

Answers to the Most Frequently Asked Questions About Drug Abuse, pamphlet published by NIMH and HEW, March 1971.

Berne, Eric, Games People Play, Grove Press, New York, 1964.

Blachly, Paul, (Personal communication, March 1971).

Blachly, Paul, Seduction as a Conceptual Model in the Drug Dependencies, University of Oregon Medical School, 1969.

Blachly, Paul, The Simplest Methadone Blockade Treatment Program, a paper presented at the APA meeting in San Francisco, May 1970.

Blachly, Paul, Sam Irwin, and John Marks, (were funded a research grant March 1971, by NIMH) "Effects of Long Term Drug Dependency."

Diagnostic and Statistical Manual of Mental Disorders, Published by APA, 2nd Edition, 1968.

Doer, Dale, "The Law on Narcotic and Non-Narcotic Drugs," Drug Abuse: A Course for Educator, ed. by Melvin Weinswig, Indianapolis, Indiana, Butler University, 1968, p. 106.

Dole, Vincent and Alan Warner, "Evaluation of Narcotics Treatment Programs," American Journal of Public Health, vol. 57, 1967, pp. 2000-5.

Dole, Vincent, Waymond Robinson, John Orraca, Edward Towns, Paul Searcy, and Eric Caine, "Methadone Treatment of Randomly Selected Criminal Addicts," New England Journal of Medicine, June 19, 1969, pp. 1372-5.

Dole, Vincent, Marie Nyswander, and Mary Kreek, "Narcotic Blockade," Archives of Internal Medicine, vol. 118, Oct. 1966, pp.304-9.

Dole, Vincent, Marie Nyswander, "Rehabilitation of Heroin Addicts after Blockade with Methadone," New York Journal of Medicine, vol.66, August 1, 1966, pp. 2011-17.

Dole, Vincent, Marie Nyswander, and Alan Warner, "Successful Treatment of 750 Criminal Addicts, "Journal of the American Medical Association, vol. 206, Dec. 16, 1968, pp. 2708-11.

Ellsworth, Robert, "Hospital and Community Adjustment as Perceived by Psychiatric Patients, Their Families, and Staff, "Journal of Consulting and Clinical Psychology, vol. 32, no. 5, part 2, Oct. 1968, pp. 1-44. 


\section{CONTINUED}

Ellsworth, Robert, Personal Adjustment and Role Skills (Questionnaire), Aug. 1968, reproduction from the Executive Dept. State of Oregon.

Erikson, Steve, "Leaders Clash on Effectiveness of Methadone as Aid to Drug Addicts," Oregonian, Dec. 9, 1970, p.38.

Expanding Theory and Practice in Family Therapy, Eds: Nathan Ackerman, Frances Beatman, and Sanford Sherman, Family Service Assn. of America, N. Y., 1967.

Framo, James, Rationale and Techniques of Intensive Family Therapy in Intensive Family Therapy; Theoretical and Practical Aspects, Eds: Ivan Boszormenyi Nagy and James L. Framo, Harper and Row, 1965, pp. $143 \cdots 212$.

Haley, Jay, Strategies of Psychotherapy, N. Y., Grune and Stratton, 1963.

Maurer, David, "The Subculture of the Criminal Narcotic Addict, " Drug Abuse: Data and Debate, Ed. by Paul Blachly, Charies Thomas Publisher, Springfield, III. , 1970, pp. $14 \cdot 48$.

Methadone Maintenance Evaluation Committee, "Progress Report of Evaluation of Methadone Maintenance Treatment Program as of March 31, 1968, "Journal of the American Medical Association, vol. 206, no. 12, Dec. 16, 1968, pp. 2712-4.

Nyswander, Marie, "The Methadone Treatment of Heroin Addiction," Hospital Practice, April 1967, pp. 27-33.

Pearson, Barbara, "Methadone Maintenance in Heroin Addiction: The Program at Beth Israel Medical Center," American Journal of Nursing, vol. 70, no. 12, Dec. 1970 , pp. 2571-4.

"Progress Report of Synthetic Narcotic Blockade Treatment Program for the Period April 2, 1969 to July 1, 1970." The Committee Relating to Drug Dependency State of Oregon. Legislative Assembly.

Ramer, Barry, Marshall Zaslove and Joan Langan, "Is Methadonc Enough: The Use of Ancillary Treatment During Methadone Maintenance," American Journal of Psychiatry, vol. 127, no. 8, Feb. 1971, pp. 1040\%4.

"Reported to the Committee on Problems of Drug Dependence 1970, "National Academy of Science, National Research Council, Division of Medical Sciences, Washington, D. C.

Satir, Virginia, Conjoint Family Therapy, Science and Behavior Books, Inc., 1964. 


\section{METHADONE BLOCKADE TREATMENT PROGRAM}

General Information:

The purpose of this questionnaire is to assist the Methadone Treatment Program in working with you and others. Approximately 50 other people in Methadone Treatment will be given this questionnaire. All information you give will be strictly confidential, and your name will not be disclosed. Please keep in mind that your answers will not influence your treatment or affect your status on the program in any way. Your frank response will be necessary if this questionnaire is to be of any help in better understanding your situation. It will also help us in future planning so that we can better answer your needs and the needs of others like you. We thank you for your time and assistance. The questionnaire should take approximately 15 minutes to complete.

A. Name:

Age:

Race:

Sex: Level of education completed:

Marital status: Single

No. of children:

\begin{tabular}{ll}
\hline & Single \\
\hline & Marriage intact \\
\hline & Marriage broken
\end{tabular}

B. 1. Age of onset of addiction to heroin:

2. How many years have you used heroin?

3. Number of prior formal treatments for heroin addiction:

4. How long have you been using Methadone?

5. Who referred you to the Methadone Program?

News Media (TV, Radio, Newspaper)

Client Friend

Public Agency

Detoxification facility

Methadone staff member

6. How often do you come to the Methadone Clinic?

When did you come last? 
Please read carefully the following questions. Mark (X) the choice or choices (where indicated) which best describe your situation.

I.

1. During the last month have you taken part in recreational activities outside the home (such as movies, dances, bowling, sports, etc.)? (Mark one)
(24\%) Never
(26\%) Rarely (once or twice last month)
(32\%) Sometimes (3-5 times last month)
(12\%) Often (6-12 times last month)
( $6 \%)$ Very often (13 or more times last month)
$\mathrm{N}=50$

2. During the last month were you involved in few interests outside the home or a wide variety of outside interests? (Mark one)

(22\%) No outside interests

(20\%) Rarely involved in outs ide interests

(Once or twice last month)

(32\%) Sometimes involved in outside interests (3-5 times last month)

(20\%) Moderate involvement in outside interests (6-12 times last month)

(6\%) Very much involvement in outside interests (13 or more times last month)

$\mathrm{N}=50$

3. During the last month did you spend time with family members (including in-laws?) (Mark one)

(24\%) Rarely (Once or twice last month)

(20\%) Sometimes (3-5 times last month)

(18\%) Often (6-12 times last month)

( $8 \%)$ Usually (13-25 times last month)

(30\%) Always (26 or more times last month)

$N=50$ 
4. Since starting on Methadone which one of the following applies to your relationship with your family. (For example, parents, aunt, grandparents, brother-in-law, etc.)

(6\%) I am spending less time with my family.

(33\%) I am spending about the same amount of time with my family.

(49\%) I am spending more time with my family.

(12\%) I do not spend time with my family because we live too far apart to see each other: or they are deceased.

$$
\mathrm{N}=49
$$

List how many times you saw your family in the last month

5. During the last month have you attended the activities of organizations or social clubs? (Mark one)

(76\%) Did not attend any activities outside the home.

(12\%) Belonged to none, but occasionally attended.

( $2 \%)$ Belonged to at least one organization and sometimes attended.

( $2 \%$ ) Belonged to at least one and attended about once a month.

( $8 \%$ ) Belonged to at least one and attended more than once a month.

$\mathrm{N}=50$

If so, please list example(s):

6. Since you have been on Methadone, check any changes in your social life. (You may check more than one).

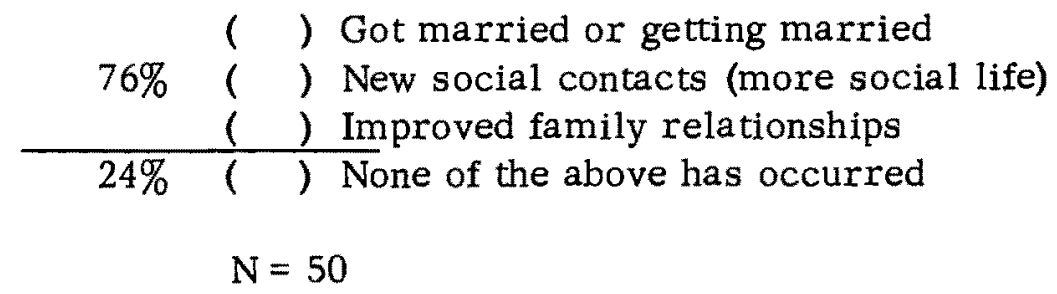


7. Since starting on Methadone do you go out more with your friends? (Mark one)

$$
\begin{aligned}
& (38 \%) \text { Yes } \\
& (60 \%) \text { No } \\
& (2 \%) \text { Have no friends } \\
& \mathrm{N}=50
\end{aligned}
$$

8. How many close friends do you have? (Mark one)

$$
\begin{aligned}
& \text { (20\%) None at present } \\
& (54 \%) \text { A few }(1-3) \\
& (12 \%) \text { Some }(4-6) \\
& (14 \%) \text { Many }(7 \text { or more) } \\
& N=50
\end{aligned}
$$

9. Are your friends mostly... (Mark one)

$$
\begin{aligned}
& (8 \%) \text { Addicts } \\
& (20 \%) \text { Ex-addicts } \\
& (58 \%) \text { Non-users } \\
& (14 \%) \text { Have no friends } \\
& \mathrm{N}=50
\end{aligned}
$$


II.

1. Which of the following most clearly describes your living arrangements during the last month? (Mark one)

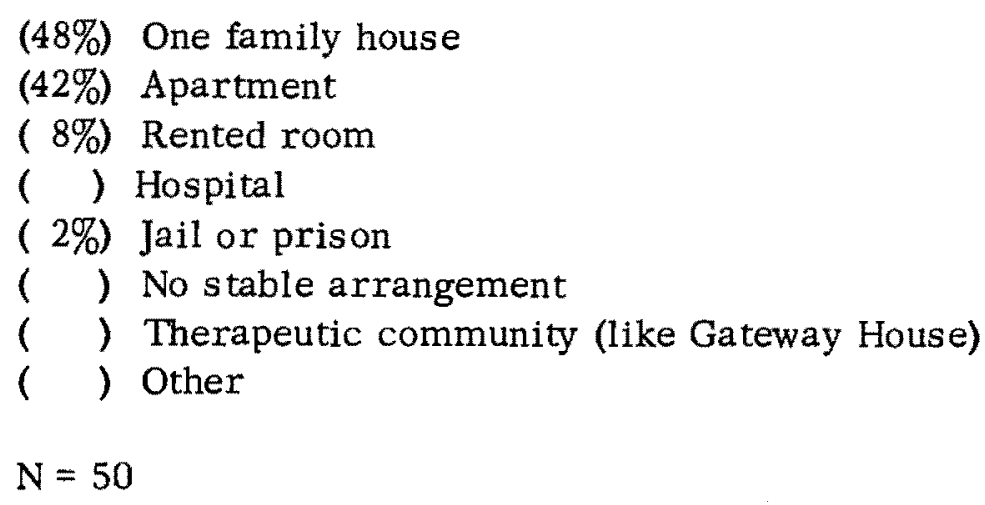

2. With whom were you living during most of the past month? (Mark one)

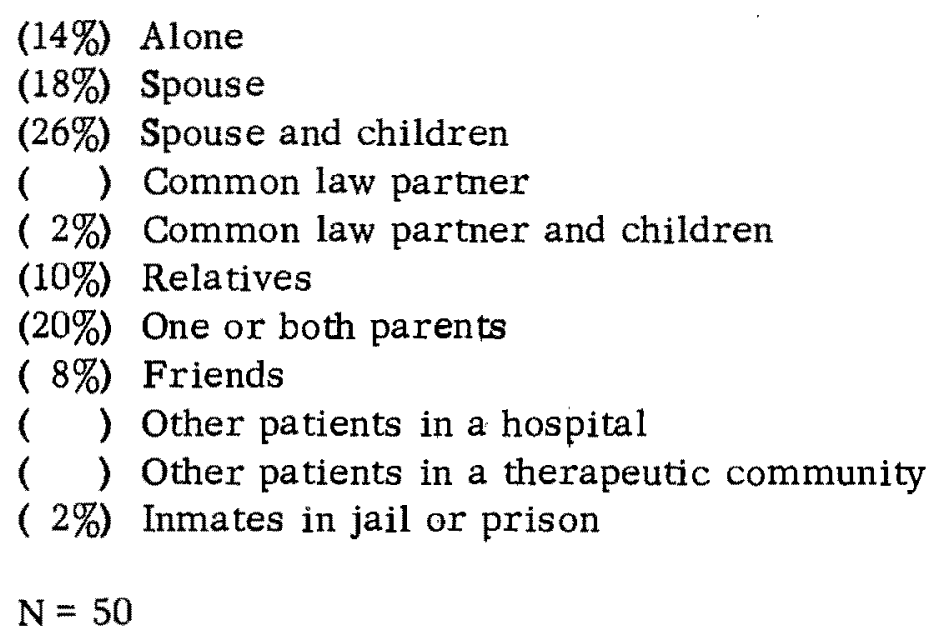

3. Which best describes the person(s) you marked in question number 2 above? (Mark any that apply)

(67\%) Never used illegal drugs

(18\%) No longer using illegal drugs (quit and/or on Methadone Program)

( ) Now using illegal drugs

(15\%) Heavy use of alcohol

() I live alone

$N=49$ 
4. During the last month have you looked for or obtained employment? (Mark one)

( $2 \%$ ) Unemployed, didn't want to look for work

( $6 \%$ ) Unemployed, wanted to work but didn't seek it

(13\%) Occasionally went out and looked for work

(14\%) Frequently went out and looked for work

(65\%) Was employed

$\mathrm{N}=48$

5. Are you currently involved in vocational training or another kind of formal education? (Mark one)

(18\%) Yes - Name

(22\%) No (would not care to be)

$(60 \%)$ Would like to be in school or training

$\mathrm{N}=50$

6. During the last month, which best describes your legitimate paying job?

(Mark one)

(52\%) Working for someone else (stable job)

( $8 \%$ ) Self-e mployed (stable situation)

( $2 \%$ ) Occasional "gig" or free lance

(musician, artist, etc.)

( $8 \%$ ) Odd jobs (fill-in work or unstable situation)

(30\%) None of the above

$N=50$

If you worked, please list type of work and name of business.

7. About how much money did you legally earn during the last month? (Mark one)

(20\%) Earned no money

( $8 \%$ ) Earned less than $\$ 25$ per week

(14\%) Earned between $\$ 25$ and $\$ 50$ per week

(32\%) Earned between $\$ 50$ and $\$ 100$ per week

(26\%) Earned over $\$ 100$ per week

$N=50$ 
8. In the last month did you earn an adequate amount of money? (Mark one)

(24\%) Earned no money

(16\%) Earned enough to take care of your personal needs

(12\%) Earned enough to support only yourself

(24\%) Earned enough to partially support a family

(22\%) Earned enough to adequately support a family

( $2 \%$ ) Totally dependent on welfare assistance

$\mathrm{N}=50$

9. In the last month have you been drinking to excess? (Mark one)

(60\%) Never

(20\%) Rarely (1-2 times last month)

(12\%) Sometimes ( $3-5$ times last month)

( $6 \%$ ) Often (6-12 times last month)

( $2 \%$ ) Usually (13 or more times last month)

$N=50$

10. Have you had a drinking problem in the last month that has upset your relationship with family members? (Mark one)

$$
\begin{aligned}
& (38 \%) \text { Yes } \\
& (62 \%) \text { No } \\
& N=50
\end{aligned}
$$


III.

1. Were you on probation anytime during your first month in the Methadone Program? (Mark one)

$$
\begin{array}{ll}
(26 \%) & \text { Yes } \\
(74 \%) & \text { No } \\
N=50
\end{array}
$$

2. During the last month were you under any legal pressure, such as a parole officer, court, or by the police, to remain in treatment for your drug problem? (Mark one)

$$
\begin{aligned}
& \text { (12\%) Yes } \\
& (88 \%) \text { No } \\
& N=50
\end{aligned}
$$

3. After you started in the Methadone Program have you been on probation? (Mark one)

$$
\begin{aligned}
& (42 \%) \text { Yes } \\
& (58 \%) \text { No } \\
& N=50
\end{aligned}
$$

4. Mark the drugs you have used during the last month and the approximate number of times each was used during the last month. DO NOT mark any medications prescribed for you by this program.

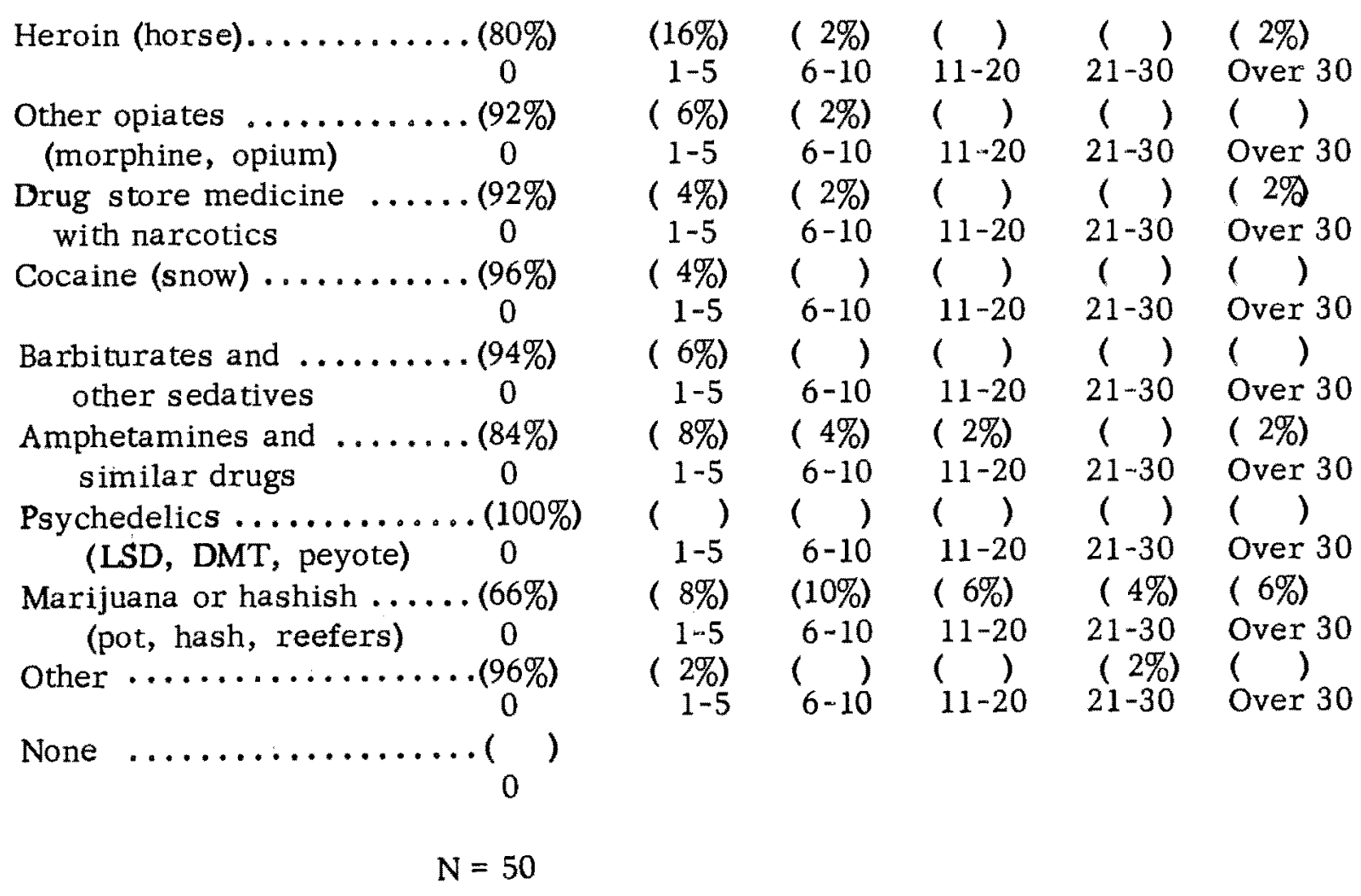


5. During the last month how much money did you spend on drugs in an average week? DO NOT include Methadone. (Mark one)

$$
\begin{array}{rlc}
(64 \%) & \$ & 0 \\
(34 \%) & \$ & 1-\$ 50 \\
(\quad) & \$ & 51-\$ 100 \\
(\quad) & \$ & 101-\$ 200 \\
(\quad) & \$ & 201-\$ 300 \\
(2 \%) & \$ & 301-\$ 500 \\
(\quad) & \$ 501 \text { or more } \\
\mathrm{N}=49 &
\end{array}
$$

6. One year before beginning Methadone Treatment how many times were you arrested? (Mark one)

$$
\begin{aligned}
& \text { (48\%) } 0 \\
& \text { (48\%) } \quad 1-4 \\
& \text { ( } 2 \% \text { ) 5-9 } \\
& \text { ( } 2 \%) 10 \text { or more } \\
& \mathrm{N}=50
\end{aligned}
$$

7. Since beginning treatment in the Methadone Program, how many times have you been arrested? (Mark one)

$$
\begin{array}{ll}
(68 \%) & 0 \\
(32 \%) & 1-3 \\
(\quad) & 4-7 \\
(\quad) & 8 \text { or more } \\
N=50
\end{array}
$$

8. Were you picked up by the police during the last month? If so, mark number of times. (Mark one)

$$
\begin{array}{ll}
(80 \%) & 0 \\
(20 \%) & 1-3 \\
(\quad) & 4-7 \\
(\quad) & 8 \text { or more } \\
\mathrm{N}= & 50
\end{array}
$$


9. Mark all of the following that applied to you during the last month. (You may mark more than one)

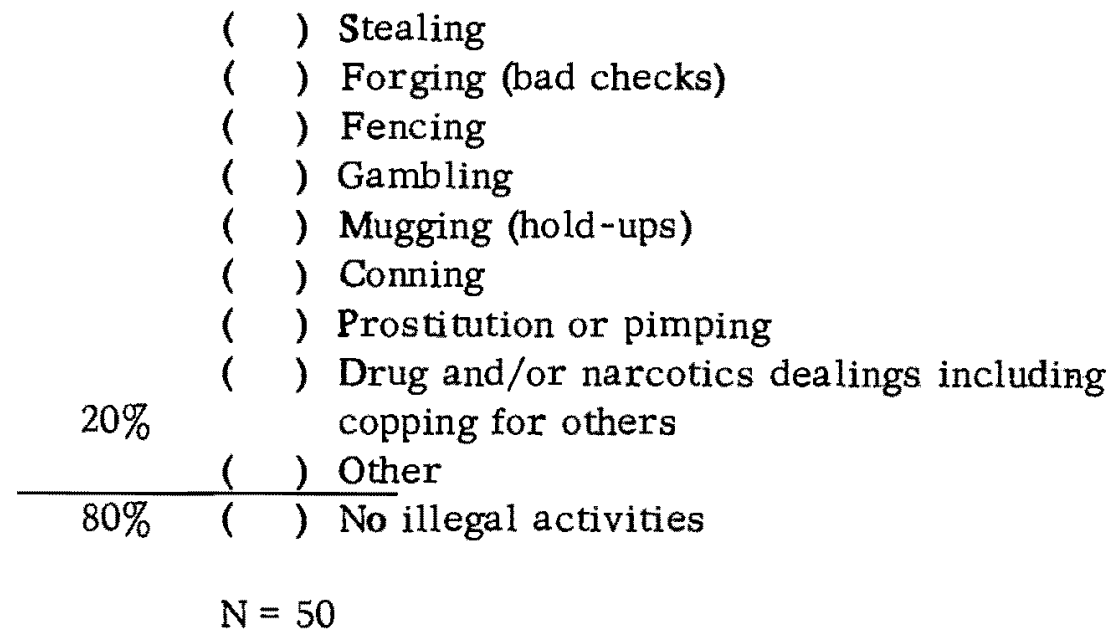

10. How much money did you make from all non-legitimate sources listed in question 9 during the last month? (Mark one)

$$
\begin{aligned}
& (85 \%) \quad \$ 0 \\
& \text { (13\%) } \$ 1-\$ 50 \\
& \text { ( ) } \$ 51-\$ 100 \\
& \text { ( ) } \$ 101-\$ 200 \\
& \text { ( ) } \$ 201-\$ 300 \\
& \text { (2\%) } \$ 301-\$ 500 \\
& \text { ( ) } \$ 501 \text { or more } \\
& \mathrm{N}=49
\end{aligned}
$$

11. How is your life different now than before you started Methadone Treatment? 


\section{A LCOHOL \& DRUG SECTION \\ MENTA L HEA LTH DIVISION \\ METHADONE BLOCKADE TREATMENT PROGRAM}

Sixth Floor Henry Building, 309 S. W. Fourth Avenue, Portland, Oregon 97204

$223-6234$

\section{DA TE}

To further help us in meeting your needs and increasing our understanding of your situation, and other people in the program, we would like to talk with a person who is close to you. This person should have known you before starting on Methadone and now. We would prefer if it were your spouse, common-law partner, or parents, for example. This person must live in the Portland Area. We will ask the person you choose to fill out a questionnaire similar to the one you have just completed. All information received will be held in confidence and will not be exchanged with the pers on you select to complete the questions.

I , hereby authorize and request $\mathrm{Mr}$. Richard

Cox or Mr. Gary West to give the questionnaire to:

Name

Relation

Address

Phone No.

Methadone Program Director

Signature of Patient

Researcher

Researcher 


\title{
Appendix B \\ Informant Questionnaire and Percentages of Responses \\ METHADONE BLOCKADE TREATMENT PROGRAM
}

General Information:

The purpose of this questionnaire is to assist the Methadone staff members in working with the people on the program. Approximately 50 other people will be given this questionnaire. All information you give will be strictly confiden tial, and your name will not be disclosed. Please keep in mind that your responses will not be given to the patient, or influence his treatment or affect his status on the program in any way. Your frank response will be necessary if this study is to be of any help to the people this program serves. It will also help us in future planning. We thank you for your time and assistance. This questionnaire should take approximately 15 minutes to complete.

Please read carefully the following questions. Mark (X) the choice or choices (where indicated) which best describes this person and his situation.

How long have you known this person?

How often do you see him?

I。

1. During the last month has he taken part in recreational activities outside the home (such as movies, dances, bowling, sports, etc.?) (Mark one)

\author{
(23\%) Never \\ (38\%) Rarely (once or twice last month) \\ (20\%) Sometimes (3-5 times last month) \\ (19\%) Often (6-12 times last month) \\ ( $0 \%$ ) Very often (13 or more times last month) \\ $\mathrm{N}=48$
}


2. During the last month has he been involved in few interests outside the home or a wide variety of outside interests? (Mark one)

(30\%) No outside interests

(18\%) Rarely involved in outside interests (once or twice last month)

(28\%) Sometimes involved in outside interests (3-5 times last month)

(14\%) Moderate involvement in outside interests (6-12 times last month)

(10\%) Very much involvement in outside interests (13 or more times last month)

$$
N=48
$$

3. During the last month has he spend time with family members (including in-laws?) (Mark one)

(14\%) Rarely (once or twice a month)

(6\%) Sometimes (3-5 times last month)

(19\%) Often (6-12 times last month)

(10\%) Usually (13-25 times last month)

(51\%) Always (26 or more times last month)

$N=47$

4. Since starting on Methadone which one of the following applies to his relationship with his family. (For example, parents, aunt, grandparents, brother-in-law, etc.)

( $6 \%$ ) He is spending less time with his family

$(29 \%)$ He is spending about the same amount of time with his family

(53\%) He is spending more time with his family

$(12 \%)$ He does not spend time with his family because they live too far apart to see each other: or they are deceased.

$\mathrm{N}=47$

List how many times he saw his family in the last month 
5. During the last month has he attended the activities of organizations or social clubs? (Mark one)

(81\%) Did not attend any activities outs ide the home ( $4 \%$ ) Belonged to none, but occasionally attended

(11\%) Belonged to at least one organization and sometimes attended.

( ) Belonged to at least one and attended about once a month

( $4 \%$ ) Belonged to at least one and attended more than once a month

$\mathrm{N}=48$

If so, please list example(s):

6. Since he has been on Methadone, check any changes in his social life. (You may check more than one).

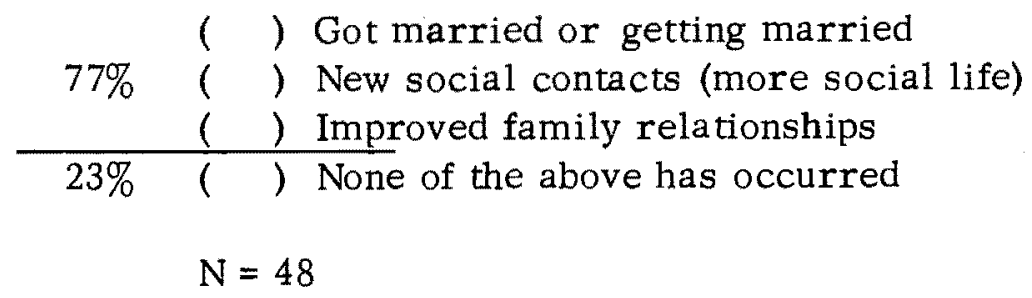

7. Since starting on Methadone does he go out more with his friends? (Mark one)

(26\%) Yes

(72\%) No

( $2 \%$ ) Has no friends

$N=47$ 
8. How many close friends does he have? (Mark one)

(16\%) None at present

(55\%) A few $(1-3)$

( 6\%) Some $(4-6)$

(23\%) Many (7 or more)

$$
N=48
$$

9. Are his friends mostly. . . (Mark one)

$$
\begin{aligned}
& (11 \%) \text { Addicts } \\
& (22 \%) \text { Ex-addicts } \\
& (53 \%) \text { Non-users } \\
& (14 \%) \text { Has no friends } \\
& N=47
\end{aligned}
$$


II.

1. Which of the following most clearly describes his living arrangements during the last month? (Mark one)

(50\%) One family house

(38\%) Apartment

( $8 \%)$ Rented room

( ) Hospital

( $4 \%$ ) Jail or prison

( ) No stable arrangement

( ) Therapeutic community (Like Gateway House)

( ) Other

$N=50$

2. With whom was he living during most of the last month? (Mark one)

(12\%) Alone

(14\%) Spouse

(26\%) Spouse and children

( $6 \%$ ) Common law partner

( $2 \%$ ) Common law partner and children

(12\%) Relatives

(18\%) One or both parents

(6\%) Friends

( ) Other patients in a hospital

( ) Other patients in a therapeutic community

( $4 \%$ ) Inmates in jail or prison

$\mathrm{N}=50$

3. Which best describes the person(s) marked in question number 2 above? (Mark any that apply)

(63\%) Never used illegal drugs

(24\%) No longer using illegal drugs (quit and/or on Methadone Program)

( ) Now using illegal drugs

( ) Heavy use of alcohol

(13\% He lives alone

$N=46$ 
4. During the last month has he looked for or obtained employment? (Mark one)

( $6 \%$ ) Unemployed, didn't want to look for work

( $6 \%$ ) Unemployed, wanted to look for work but didn't seek it

(12\%) Occasionally went out and looked for work

(15\%) Frequently went out and looked for work

(61\%) He was employed

$N=49$

5. Is he currently involved in vocational training or another kind of formal education? (Mark one)

(21\%) Yes - Name

(19\%) No (would not care to be)

(60\%) Would like to be in school

$\mathrm{N}=47$

6. During the last month, which best describes his legitimate paying job? (Mark one)

(47\%) Working for someone else (stable job)

( 6\%) Self-employed (stable situation)

( $2 \%$ ) Occasional "gig" or free lance (musician, artist, etc.)

(10\%) Odd jobs (fill-in work or unstable situation)

(35\%) None of the above

$\mathrm{N}=49$

If he worked, please list the type of work and name of business . 
7. About how much money did he legally earn during the last month? (Mark one)

(29\%) Earned no money

(11\%) Earned less than $\$ 25$ per week

( $2 \%$ ) Earned between $\$ 25$ and $\$ 50$ per week

(33\%) Earned between $\$ 50$ and $\$ 100$ per week

(25\%) Earned over $\$ 100$ per week

$\mathrm{N}=48$

8. In the last month did he earn an adequate amount of money? (Mark one)

(26\%) Earned no money

(13\%) Earned enough to take care of his personal needs

(14\%) Earned enough to support only himself

(13\%) Earned enough to partially support a family

(28\%) Earned enough to adequately support a family

(6\%) Totally dependent on welfare assistance

$N=48$

9. In the past month has he been drinking to excess? (Mark one)

(58\%) Never

(23\%) Rarely (1-2 times last month)

(11\%) Sometimes (3-5 times last month)

(4\%) Often (6-12 times last month)

( $4 \%$ ) Usually (13 or more times last month)

$\mathrm{N}=47$

10. Has he had a drinking problem in the last month that has upset his relationship with family members? (Mark one)

(48\%) Yes

(52\%) No

$N=49$ 
III.

1. Was he on probation anytime during the first month in the Methadone Program? (Mark one)

$$
\begin{aligned}
& (32 \%) \text { Yes } \\
& (68 \%) \text { No } \\
& N=47
\end{aligned}
$$

2. During the last month was he under any legal pressure, such as parole officer, court, or by the police, to remain in treatment for his drug problem? (Mark one)

$$
\begin{aligned}
& (25 \%) \text { Yes } \\
& (75 \%) \text { No } \\
& \mathrm{N}=48
\end{aligned}
$$

\begin{tabular}{|c|c|c|c|c|c|}
\hline $\begin{array}{c}\text { Heroin (horse) } \ldots \ldots \ldots \ldots \ldots(88 \%) \\
0\end{array}$ & $\begin{array}{c}(2 \%) \\
1-5\end{array}$ & $\left(\begin{array}{l}() \\
6-10\end{array}\right.$ & $\begin{array}{l}(1) \\
11-20\end{array}$ & $\begin{array}{c}(\quad) \\
21-30\end{array}$ & $\begin{array}{c}(c) \\
\text { Over } 30\end{array}$ \\
\hline Other opiates. & $(2 \%)$ & & & & \\
\hline (morphine, opium) & $1-5$ & $6-10$ & $11-20$ & $21-30$ & Over 30 \\
\hline Drug store medicine $\ldots . . .(82 \%)$ & & $(2 \%)$ & $(4 \%)$ & & $(2 \%)$ \\
\hline with narcotics & $1-5$ & $6-10$ & $11-20$ & $21-30$ & Over 30 \\
\hline $\begin{array}{c}\text { Cocaine }(\text { snow }) \ldots \ldots \ldots . . .(88 \%) \\
0\end{array}$ & $\begin{array}{c}(2 \%) \\
1-5\end{array}$ & $\left(\begin{array}{l}() \\
6-10\end{array}\right.$ & $\begin{array}{c}(1) \\
11-20\end{array}$ & $\begin{array}{l}(\quad) \\
21-30\end{array}$ & $\begin{array}{c}(1) \\
\text { Over } 30\end{array}$ \\
\hline $\begin{array}{c}\text { Barbiturates and } \ldots \ldots \ldots \ldots(88 \%) \\
\text { other sedatives }\end{array}$ & $\begin{array}{c}(2 \%) \\
1-5\end{array}$ & $\left(\begin{array}{l}() \\
6-10\end{array}\right.$ & $\begin{array}{c}(1) \\
11-20\end{array}$ & $\begin{array}{l}(1) \\
21-30\end{array}$ & $\begin{array}{l}(1) \\
\text { Over } 30\end{array}$ \\
\hline $\begin{array}{c}\text { Amphetamines and } \ldots \ldots \ldots(88 \%) \\
\text { similar drugs }\end{array}$ & $\begin{array}{c}(2 \%) \\
1-5\end{array}$ & $\left(\begin{array}{l}() \\
6-10\end{array}\right.$ & $\underset{11-20}{()}$ & $\begin{array}{l}(\quad) \\
21-30\end{array}$ & $\begin{array}{l}(\quad) \\
\text { Over } 30\end{array}$ \\
\hline 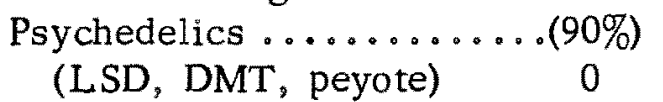 & $(\underset{1-5}{)})$ & $\left(\begin{array}{r}() \\
6-10\end{array}\right.$ & $\begin{array}{l}(r) \\
11-20\end{array}$ & $\begin{array}{l}(1) \\
21-30\end{array}$ & $\begin{array}{l}(1) \\
\text { Over } 30\end{array}$ \\
\hline $\begin{array}{c}\text { Marijuana or hashish } \ldots . . .(78 \%) \\
\text { (pot, hash, reefers) }\end{array}$ & $\begin{array}{c}\left(\begin{array}{c}4 \% \\
1-5\end{array}\right) \\
-5\end{array}$ & $\begin{array}{r}(2 \%) \\
6-10\end{array}$ & $\begin{array}{l}(4 \%) \\
11-20\end{array}$ & $\begin{array}{l}(r) \\
21-30\end{array}$ & $\begin{array}{l}(2 \%) \\
\text { Over } 30\end{array}$ \\
\hline $\begin{array}{c}\text { Other } \ldots \ldots \ldots \ldots \ldots \ldots(86 \%) \\
0\end{array}$ & $\begin{array}{c}(2 \%) \\
1-5\end{array}$ & $\left(\begin{array}{r}() \\
6-10\end{array}\right.$ & $\begin{array}{l}(1) \\
11-20\end{array}$ & $\begin{array}{l}(2 \%) \\
21-30\end{array}$ & $\begin{array}{l}(\stackrel{)}{)} \\
\text { Over } 30\end{array}$ \\
\hline None $\left.\ldots \ldots \ldots \ldots \ldots \ldots{ }_{0}\right)$ & $* 10 \% \mathrm{R}$ & onded & on't $\mathrm{K}$ & & \\
\hline
\end{tabular}

3. After he started in the Methadone Program has he been on probation? (Mark one)

$$
\begin{aligned}
& (38 \%) \text { Yes } \\
& (62 \%) \text { No } \\
& N=48
\end{aligned}
$$

4. Mark the drugs he has used during the last month and the approximate number of times each was used during the last month. DO NOT mark any medications prescribed for him by this program. * 
5. During the last month how much money did he spend on drugs in an average week? DO NOT include Methadone. (Mark one)

$$
\begin{array}{lll}
(75 \%) & \$ & 0 \\
(19 \%) & \$ 1 & -\$ 50 \\
(4 \%) & \$ 51-\$ 100 \\
(2 \%) & \$ 101-\$ 200 \\
(\quad) & \$ 201-\$ 300 \\
(\quad) & \$ 301-\$ 500 \\
(\quad) & \$ 501 \text { or more } \\
\mathrm{N}=46 &
\end{array}
$$

6. One year before beginning Methadone Treatment how many times was he arrested? (Mark one)

$$
\begin{array}{ll}
(53 \%) & 0 \\
(43 \%) & 1-4 \\
(2 \%) & 5-9 \\
(2 \%) & 10 \text { or more } \\
N=44
\end{array}
$$

7. Since beginning treatment in the Methadone Program, how many times has he been arrested? (Mark one)

$$
\begin{array}{ll}
(72 \%) & 0 \\
(28 \%) & 1-3 \\
(\quad) & 4-7 \\
() & 8 \text { or more } \\
N=47
\end{array}
$$

8. Was he picked up by the police during the last month? If so, mark the number of times. (Mark one)

$$
\begin{array}{ll}
(91 \%) & 0 \\
(9 \%) & 1-3 \\
(\quad) & 4-7 \\
(\quad) & 8 \text { or more } \\
\mathrm{N}=47
\end{array}
$$


9. Mark all of the following which applied to him during the last month. (You may mark more than one).

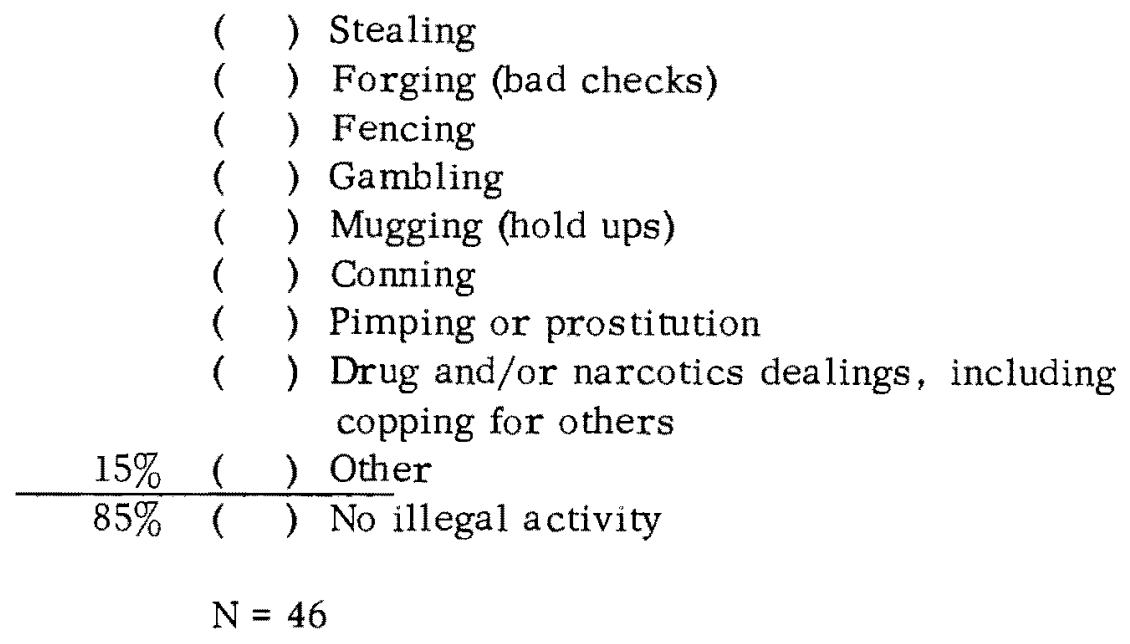

10. How much money did he make from all non-legitimate sources listed in question 9 during the last month? (Mark one)

$$
\begin{aligned}
& \text { (83\%) \$ } 0 \\
& (11 \%) \$ 1-\$ 50 \\
& \text { ( } 2 \%) \$ 51-\$ 100 \\
& \text { (2\%) } \$ 101-\$ 200 \\
& \text { ( } 2 \%) \$ 201-\$ 300 \\
& \text { ( ) } \$ 301-\$ 500 \\
& \text { ( ) } \$ 501 \text { or more } \\
& \mathrm{N}=45
\end{aligned}
$$

11. How is his life different now than before he started Methadone Treatment? 


\section{Appendix C}

Percentage of Perfect Agreement Between Patient and Informant for Each Question and ProductMoment Correlations for Scalable Items

Section I

Question 1

During the last month have you (has he) taken part in recreational activities outside the home

(such as movies, dances, bowling, sports, etc.?)

$36 \%$

Question 2

During the last month have you (has he) been involved in few interests outside the home or a wide variety of outside interests?

Question 3

During the last month have you (has he) spent time with family members (including in-laws)?

\section{Question 4}

Since starting $\mid$ on Methadone which one of the following applies to your (his) relationship with your (his)

family? (For example, parents, aunt, grandparents, brother-in law, etc.)

\section{Question 5}

During the last month have you (has he) attended the activities of organizations or social clubs?

\section{Question 6}

Since you have (he has) been on Methadone check any changes in your (his) social life.

*r's recorded where applicable. Significance levels are as follows: $>.273=.05 ; \quad>354=.01$ 
Question 7

Since starting on Methadone do you (does he) go out more with your (his) friends?

$58 \%$

Question 8

How many close friends do you (does he) have?

$42 \%$

Question 9

Are your (his) friends mostly...

$51 \%$ 
Question 1

Which of the following most clearly describes your (his) living arrangement during the last month?

Question 2

With whom were you (was he) living during most of the last month?

Question 3

Which best describes the person(s) marked in question 2 above?

Question 4

During the last month have you (has he) looked for or obtained employment?

Question 5

Are you (is he) currently involved in vocational training or another kind of formal education?

Question 6

During the last month, which best describes your (his) legitimate paying job?

Question 7

About how much money did you (he) legally earn during the last month?

\section{Question 8}

In the last month did you (he) earn an adequate amount of money? 
Question 9

In the past month have you (has he) been drinking to excess?

$62 \%$

0.60

Question 10

Have you (has he) had a drinking problem in the last month that has upset your (his) relationship with family members?

$95 \%$ 
Question 1

Were you (was he) on probation anytime during the first month in the Methadone Program?

$87 \%$

Question 2

During the last month were you (was he) under any legal pressure, such as parole officer, court, or by the police, to remain in treatment for your (his) drug problem?

$79 \%$

Question 3

After you (he) started in the Methadone Program have you (has he) been on probation?

$83 \%$

Question 4

Mark the drugs you have (he has) used during the last month and the approximate number of times each was used during the last month.

$\begin{array}{lr}\text { Heroin } & 81 \% \\ \text { Other opiates } & 89 \% \\ \text { Drug store medicine } & \\ \quad \text { with narcotics } & 84 \% \\ \text { Cocaine } & 93 \% \\ \text { Barbiturates } & 91 \% \\ \text { Amphetamines } & 80 \% \\ \text { Psychedelics } & 100 \% \\ \text { Marijuana or hashish } & 62 \% \\ \text { Other } & 94 \%\end{array}$

Question 5

During the last month how much money did you (did he) spend on drugs in an average week?

$63 \%$

0.37

Question 6

One year before beginning Methadone Treatment how many times were you (was he) arrested? 
Question 7

Since beginning treatment in the Methadone

Program, how many times have you (has he) been arrested?

Question 8

Were you (was he) picked up by the police during the last month?

\section{Question 9}

Mark all of the following which applied to you (to him) during the last month.

\section{Question 10}

How much money did you (did he) make from all non-legitimate sources listed in question 9 during the last month? 
Appendix D

Patient Sample Characteristics

Table D I

Onset of Addiction

$$
\mathrm{N}=48
$$
$13=20$ Years
$21-25$
$26-30$
$31-25$
$32=67 \%$
$11=23 \%$
$4=8 \%$
$1=2 \%$

Number of Years Narcotics Used

$$
\mathrm{N}=47
$$

1 2 Years

$11=23 \%$

$3-5$

$6-10$

$8=17 \%$

$14=30 \%$

Table D III

Number of Prior Formal Treatments

$$
\mathrm{N}=48
$$

0

1

2

3

4

5 or more

$23=48 \% \quad 10=21 \%$

$5=10 \%$

$1=2 \%$

$3=6 \%$

$6=13 \%$
11 or more

$14=30 \%$

Table D IV

Number of Months on Methadone

$$
\mathrm{N}=48
$$

3 Months

$5=10 \%$
$4-5$

$6=13 \%$

$$
6-8
$$

$17=35 \%$
$9-12$

$10=21 \%$ 
Table D V

Marital Status

$$
\mathrm{N}=49
$$

\section{Single}

$13=26 \%$
Marriage Intact

$22=45 \%$
Marriage Broken

$$
14=29 \%
$$

Table D VI

Number of Children

$$
\mathrm{N}=50
$$

None

$$
\text { One }
$$

Two

Three

$25=50 \%$

$9=18 \%$

$6=12 \%$

$4=8 \%$
Four or more

$6=12 \%$
Table D VII

Level of Educational Achievement

$$
\mathrm{N}=48
$$

Grade Schoo]

Some H.S.

H. S. Graduation or GED

Some College or training

College

Degree

$$
4=8 \%
$$

$22=46 \%$

$12=25 \%$

$1=2 \%$ 
Appendix E

Informant Sample Characteristics

Table E I

$\underline{\text { Relationship of the Informant to the Patient }}$

$$
\mathrm{N}=50
$$

Mother

Father

Wife

Ex-wife

Wife on Program

Common Law Partner

Male Friend on Program

Male Friend

Female Friend

Uncle

Brother

Counselor

$$
\begin{aligned}
10 & =20 \% \\
6 & =12 \% \\
15 & =30 \% \\
1 & =2 \% \\
4 & =8 \% \\
2 & =4 \% \\
4 & =8 \% \\
3 & =6 \% \\
2 & =4 \% \\
1 & =2 \% \\
1 & =2 \% \\
1 & =2 \%
\end{aligned}
$$




\section{Table E II}

Length of Time Informants Have Known the Patient

$$
N=50
$$

Less Than 6 Months

6 Months To 1 Yr

1-2 Yrs. 2-5 Yrs. Or Mo

Mother

2-5Yrs.

Or More

$\underline{\%}$

\begin{tabular}{|c|c|c|c|c|c|c|}
\hline Mother & & & & & 10 & $20 \%$ \\
\hline Father & & & & & 6 & $12 \%$ \\
\hline Wife & & & 4 & 2 & 9 & $30 \%$ \\
\hline Ex-wife & & & & & 1 & $2 \%$ \\
\hline Wife on Program & & 1 & 1 & 1 & 1 & $8 \%$ \\
\hline $\begin{array}{l}\text { Common Law } \\
\text { Partmer }\end{array}$ & 1 & 1 & & & & $4 \%$ \\
\hline $\begin{array}{l}\text { Male Friend on } \\
\text { Program }\end{array}$ & & & 1 & 3 & & $8 \%$ \\
\hline Male Friend & & 1 & & 2 & & $6 \%$ \\
\hline Female Friend & & & & & 2 & $4 \%$ \\
\hline Uncle & & & & & 1 & $2 \%$ \\
\hline Brother & & & & & 1 & $2 \%$ \\
\hline Counselor & & 1 & & & & $2 \%$ \\
\hline Total & $2 \%$ & $8 \%$ & $12 \%$ & $16 \%$ & $62 \%$ & $100 \%$ \\
\hline
\end{tabular}


Table E III

Times Per Month Informants Had Contact With The Patient

$$
\begin{gathered}
\mathrm{N}=50 \\
\underline{1-5} \quad \underline{6-10} \quad \underline{11-15} \quad \underline{16-20} \quad 21 \& \text { Over } \quad \text { \% }
\end{gathered}
$$

\begin{tabular}{|c|c|c|c|c|c|c|}
\hline Father & 1 & & & 1 & 4 & $12 \%$ \\
\hline Wife & & & & 1 & 14 & $30 \%$ \\
\hline Ex-wife & & & & 1 & & $2 \%$ \\
\hline Wife on Program & & & & & 4 & $8 \%$ \\
\hline Common Law Partner & & & 1 & & 1 & $4 \%$ \\
\hline $\begin{array}{l}\text { Male Friend on } \\
\text { Program }\end{array}$ & & 1 & 1 & 1 & 1 & $8 \%$ \\
\hline Male Friend & 2 & & & & 1 & $6 \%$ \\
\hline Female Friend & & & & 1 & 1 & $4 \%$ \\
\hline Uncle & & & & & 1 & $2 \%$ \\
\hline Brother & & & & & 1 & $2 \%$ \\
\hline Counselor & 1 & & & & & $2 \%$ \\
\hline Total & $8 \%$ & $2 \%$ & $4 \%$ & $10 \%$ & $76 \%$ & $100 \%$ \\
\hline
\end{tabular}

Mother 